\title{
Some Open Issues Concerning the Resocialization of the Convicted People
}

\author{
MitasinBeqiri \\ Lecturer in the Law faculty of FON University in Skopje
}

QebirAvziu

Lecturer in the Law faculty of State University of Tetovo

\author{
Doi:10.5901/ajis.2014.v3n2p287
}

\begin{abstract}
Today, it is rightly considered that issues related to the selection and use of tools and methods with which the resocialization (treatment) is realized, has increasingly become the main issue of penology. The issues that occur as most actual and typical will be examin edhere in shortlines. Usually, when it comes to general principles the notion treatment, deals with all criminal sanctions, but it requires the application of tools and methods specific to every sanction separately, depending on its specific nature. Given the more frequent application of imprisonment, as the most used measure to fight criminality, today, without reason, the utmost attention is fixed on the treatment applied during the conduction of this sentence. Therefore, not coincidentally also this term (treatment) is exactly identified with this sentence. Regarding this definition the need for clear subject - substantial definition of the notion treatment in general and its elaboration and processs ingrelated with specific ways of implementation and execution of certain penal sanctions is also emphasized. In this regard, fully entitled are those authors who claim that the treatment for thesentencesofinstitutional characterandthoseofnon-institutionalcharactercan not (and should not) be the same. Here it comes to qualitative substantial differences that require the application of clear means and methods, defined and differentiated in the realization of resocialization.
\end{abstract}

Keywords: resocialization, prison, serving the sentence, delinquent, convict

The modern penological thinking - currently faces the issue of different attitudes about the nature of the treatment and consequently of the resocialization. More concretely, the problem is expressed through the dilemma - if resocialization is in a positive correlation report with the repression or he (the repression) precludes the realization of the process ofresocialization. More specifically - are the elements of repression implied with the resocialization? That by its essence is included in the sentence itself. With other words, herethe issue is theway of the "reconciliation" of two fundamentally different values - of the resocialization and repression which bythe nature of things are incompatible and contradictory. Some authors are deeply convinced that this components exclude each other, thus each attempt to find ways of their "coexistence" would lead to improvisation and not in findingthe answer to the aforementioned question.

In their essence, in the current level of social development, the penalties are means of repressive response to incriminating behaviour. Indeed, even the penitentiary institutions, by their constitution and their nature are typical repressive institutions, which are completely understandable, because, taken as a whole, the preventive meaning and force of penal sanctionsis based on elements of intimidation in corporated in them. For this reason, all those thoughts that lead to the conclusion that the resocialization that is implemented through various methods of treatment and that aims to reduce repression as much as possible will not correspond with the reality, However, the fact that the socialization in all penal sanctions actually contains repression, should be emphasized, but not only that this is not in the forefront, but it also differsin termsof content and is displaced to second segment, in that portionin which it should create temperance of the prisoner, self-discipline, discipline in the aspect to be fit and to accept even the treatment that is not welcomed by him. With other words, reeducation can not be based on repression initsclassical elementary meaning. For this reason, the contemporary penological thinking that bases the application of penal sanctions, especially the sentencing, on humanity, on the respect for human the dignity of the person and in elevation of the personal responsibility of the convicted, aims to eliminate, to limit and to reduce the repression as much as possible during the abovementioned implementation (Tkacevski, 1971), in order tocreatereal premisesfor resolving contradictions between the impact of repression in resocialization and realization of there-educationprocess.

Resocialization - can be realized only if the convict takes part or cooperates in this direction. But this is the area where the problem occurs. With other words howto exerciseinfluenceon the individualto cooperate when he experiences 
the sentence as something unpleasant, as a burden and often as injustice. In such a situation it is really difficult to activate the internal mechanisms that will affect the personal commitment during the process of resocialization. A lot of effort, a high degree of professionalism, great ingenuity and tactis required to determinewhichtreatment methodswith its contentandmanner of implementationwillmotivateandencouragethe inmateto becomecommittedanddisciplined. These procedures that will affect the participation of the inmate for his resocialization, will be a of great assistance in overcoming the objections that occur between socialization and repression, in the efforts for the convict to become an active factor of the reeducation process rather than its object, in which case he will not experience these actions as a liability but as a personal engagement and self-awareness inefforts totransform in life.

Study of the offender's personality -is an essential premise to achieve the objectives of. This is already an indisputable fact in penology as well as the content respectively the register of measures, of actions and activities, through which the personality of the delinquent should be analyzed, are uncontested. However, whenit comes to issues related to such a depth of the analysis, with its phases and global subjects that must be performed, many dilemmas arise. With other words, when it comes to the principle of personality analysis, usually one thinks of the activities undertaken by the competent team of the penitentiary for this purpose, in order to define the actions that need to create the content of the treatment in the penitentiary institution. But, the personality analysis implies more viewpoints, some phases and the participation of many other subjects, alongside thoseof thegroup of the professionalsector for prison admission. Thus, the initial activities that should be undertaken are related tothe creator-deedrelation. Criminal of fense clarifies a lot of important elements related to the delinquent's personality: motives, severity of the conflict and the emotional state at the time of the offense, social conditions that have determined the incriminating act. With other words, the personality analysis also includes the prosecution bodies precisely taking measures that are important not only to prove guilt, to conclude the responsibility and to sentence, but also because they are in direct function of the resocialization, that is very essential from the viewpoint of the issue that is elaborated. Forthese reasons, during the proceedings of the so-called classical measures related to the discovery and examination of the act, the body of attendance has to access and reveal the reasons that caused the perpetratorto do that exact offense in that exact manner, from another viewpoint.

In other words, respect not only for the penal - juridical aspects but also the criminological - legal aspects of the act and of its perpetrator. For these reasons, the personality analysis of the delinquent begins much earlier. Thus, the penal proceeding whose final purpose is the implementation of the penal sanction and prevention of the delinquent forcommitting of fenses in the future gets another function, emphasizing the necessity for the process of resocialization to begin much earlier, respectively ever since the first processor measures against the delinquent are taken. Otherwise, all these proceedings will be in the function of the requests oriented towards the change of the character of repression or relief of it - approach that will directly contribute for the successful and comprehensive realization of the purposes of penalty and resocialization.

Setting socialization as a fundamental purpose of the enforcement of penal sanctions simultaneously stresses the need for the existence of such a developed and rich penal sanctionsystem that would be consistent with the needs for specific treatment of different convicted persons, according their criminological characteristics, and their needs. In this case, thereis no claim for some system of criminal sanctions that would respond to each person, because this is neither possible nor necessary. However, within the defined and scientifically verified typologies of delinquents, it is well known that there must be a developed system of penal sanctions that will meet the needs for treatment and rehabilitation of that type and category of delinquents. From this perspective, the system of penal sanctions should be rich regarding the sanctions and the possibility that any sanction during implementation should ensure modifications in terms of duration, conditions of realization, treatment methods and procedures, etc. With other words, a developed system of penal sanctions should be characterized with the possibility for mutual combination of sanctions and for their completion or interconnection during various stages of the resocialization process (Arnaudovski, 1988; Lazareviq, 1970).

Legislative organization associated with the system of sanctions- With other words, according to the opinion of many authors, one can conclude that even though it is basically organized in a broad manner, withan extremelywide scale (from milder forms of warning to more severe imprisonment sentences) and that it is characterized by diversity, adaptability and accordance (despite the fact that its legislative width impoverishes in the practical realization) however such "high assessments" of our system of sanctions, whenit comes tocertain specificcategoriesofdelinquents (delinquency by negligence, delinquency inroad traffic, massive criminality, organized crime, etc) shouldbe taken with caution because it does not sufficiently respect the specific sides of particular types ofcrime (Kralev, 1997; Arnaudovski, 1984).

Penology, dealing with the issue of individualism of the sentence in its enforcement can not stop to treatment of these issues in legal-penal sciences where the division is still made into: legal individualism, judiciary individualism 
and penitentiary individualism. The point here is not to highlight certain specific types of individualism, but their improper harmonization and their orientation towards the fundamental goal. With other words, the meaning of any individualism of the penal sanction is the achievement of its goal of implementing, andas it is known, allthis is donein the phase of sanction implementation. If this is so, in that case preliminary stages of individualism should consider the meaning of the penitentiary individualism which basically means providing different treatment and approach in the implementation of various types of penal sanctions. The basis on which individualism is placed is different, dependant on the type of penal sanction: institutional or non-institutional.

One of the fundamental issues of realization of the definition for resocializationis the existing conditions and premises for its realizationin practice as a complete concept. With other words, an illogical condition is present that it is a new concept in implementation of penal sanctions that is realized in relatively unchanged conditions and relations in the old penitentiary institutions built upon the idea of repression and retribution, with a relatively same professional and other staff that finds very hard to change their attitude towards sentence and work style.

Issues do not stand only in penitentiary institutions but also in the entire system of determination and production of guilt as well as in the sentence that as it is known are based on the weight of the offense. Such experience rightly imposes the view that socialization can not be realized if all the organs in penal proceedings do not operate as an unique mechanism, guided by the fundamental objectivein the implementation andexecution of the sentence. Infavour of this"goes" the practiceof the courtswhereyet verdictsand othercourt acts and documents"is being talked" aboutrevenges, remorse, deterrence by punishment etc (Bauer, 1957). Also, it can be saidthattoday there are no authorswho do not accept the concept and definition of resocialization, but even these remain in the position that its realization is not possible if (besides gentle and humane) the rehabilitation content is deprived of retributive and repressive elements, and as they say, not depending on the need but as an integral part of treatment. Indeed, these elements are encountered in our legislature too. The existing Law on sanctioning uses the term "serving the sentence". Whilst it is about an unpleasant suffering, something that is experienced, about something that is felt likean evilthat mustbe overcome. This doesn't mean that the sentence should not be considered as an affliction, but in the penological sense, but because of the resocialization it should have another meaning (Peters).

Inall this bundle of unresolved issues related to rehabilitation, despite this the penitentiary institutions, namelytheir systemic organizational structureand the ability to implement the sentence through resocialization of convicted persons, appear as the central problem of modern scientific penological thinking. Previously it was said that the concept of resocialization is compromised with the insistence that it should be realized through the penitentiary system which is basically built on old concepts and anachronistic attitudes. Havingthisposition, Penology objectively came in aposition to study and analyze those conditions and factors of the penitentiary institutions that generate negative impact, that prevent or obstruct the resocialization. In this case, based on new scientific knowledge its basic tendency is to avoid the prisons of the classical type that mainly are based on frightening, segregation and in expulsion of the prisonerfrom the society.

Elaboration of these general positions for the penitentiary institutions revealed two other issues closely related to the penitentiary practice:

a. normalization ofliving conditions of the convictsin the penitentiary-correctional institutions, and

b. construction of a developed system of specialized penitentiary institutions, in which the most important position will be held by those of the open and semi-open type as well as institutions for special categories of the convicts.

c. Given the indisputable thesis that the best penitentiary systemis the one who is closer to the living conditions in freedom (Cornil, 1995), The Penology science and the penitentiary practice facedthe issue-how to ensure the resocialization of convicts during the execution of the sentencein an artificially created environment that is isolated from the life infreedomand howcan the inmate be prepared for life in freedom in such conditions (in terms of lack of freedom)?. This dilemma was in essence the basis of the idea for the normalization of the living conditions of the inmates. This idea involves two basic components.

- The first component has to do with the respect for the personality and dignity of the convicted person and his treatment as a subject. With other words, the fact that a person that doesn't respect himself and who is not respected by others, cannot be built with the system of values and norms of behavior that would be consistent with the rules that in social point of vieware verified by the prevailing systemin society.

- The other component has to do with the conditions of the penitentiary system in which the process of resocialization of the convicted person is being implemented. This, as notedabove, isan unnatural environment characterized by isolation, strict regime and specific relations. In this environment the convict is simply forced to become a good person. In this prison environment it is not very hard to maintain the 
order and discipline, to indoctrinate the convicted person; simply he is forced to become a good person. However, the purpose of execution of sentence lies not in the fact that the convict to be obedient, good and disciplined while he is imprisoned, but to be prepared for life in freedoms, to behave in accordance with the rules set by organized society. And in environments where there is no permanent control present as there was in the prison environment. Here in emerges the issue regarding the normalization of living conditions in the penitentiary-correctional institutions, such as: firstly, the living conditions, work, treatment, etc. of the convict should not differ (essentially) from the conditions of those in freedom and secondly, the prison should not present an island, on the contrary conditions for normal communication of the convict with the outside world, that will give him knowledge about the life in freedom, will give him information about what is happening outside the prison walls should be created, so that he can live with the problems and joys of the outside world, simply he should be present in the life that is flowing outside the punitive - correctional institutions.

Normalization of the living conditions in the prison means fulfilling the professional, cultural, educational, sport and physical needs of the convicted person, development of the understanding of initiative and activity fostering, with other words creation of all the premises that will affect the convict to conceive himself as a person. In these frames communications with"outside world" areof a particular importance, especially the communication with the family and working colleagues; than reaching information about the events "outside" through the means of public information. In addition, normalization of conditions in the penitentiary correctional institutions implies the common life of convicts. With other words, man is a social being who lives in groups, in communities, anditis morethan normal, it hasto do with life in prison. For this reason, authors of penology and criminology are unique when it comes to the concept that of all the existing penitentiary systems, common suffering sentence brings the convicts closer to lifein freedom.

d. On the issue of specializing the penitentiary - correctional institutions, respectively their categorization and typology according the needs for normalization of living conditions in them, special attention was given to the open and semi-open types of institution, because, as practice shows closed-type penitentiary institutions, with all its features and harsh regime, isolation, limited communication, etc, appear as a serious obstacle for the realization of the resocialization of convicted persons. Semi-open institutions function with minimal means for securing the convicts form escape and reduced means of repression and pressure on them. In these types of institutions, the convicts are involved in the process of work outside the punitive - correctional institution without greater surveillance and life is organized with minimal control, whereby especially self-initiativeand self-discipline of the convicted persons comes to expression.

\section{Resume}

Today, the modern penology shows increased interest for open type institutions because they are closer to conditions of life in freedom. But, certain dilemmas are present also. The first issue has to do with their organizational structure: should hey function as sectors within the existing penal and correctional institutions of the closed type or of the general type, or as separate penal and correctional institutions. Regarding this dilemma, some authors rightly consider that the closed type institutions situated within the houses of general character have advantage because in this manner (with specialized staff) continuity of treatment or as some say, "this form of organization presents pedagogical closed field" is ensured (Lamers, 1961).

The other dilemma has to do with issues regarding instructing the sentenced personsin the institutions of open type, specifically whether they be instructed in those institutions directly or after servinga part of the sentence in the closed type institution. Today, more and more often the opinion that this should depend on the characteristics of delinquent's personality with all his complexities studied and analyzed in the sectors of admission or observation centres, prevails. In this regard, delinquents who meet certain criteria, respectively those who received socio - criminological positive amnesia, will be instructed directly to the open institutions, whilst others that are concluded for a certain verification of the re-education processset, should be subject to acertain degree of resocialization in the institution of other type. Their direction to open institutions will take place according to the principle of progress (Srzentiq, 1975).

\section{Reference}

Arnaudovski, L. (1988). Penology. Skopje.

Arnaudovksi, L. (1984). Penoloskiaspektinasoobraqajnatadelikvencija, Zborniknatrudovi, Skopje. 
Bauer, F. (1957). Das Verbrechen und die Geselschaft, Munich.

Cornil, P. (1955). La peine de prison, Revue internationale de Criminologie et de technigue, Geneva.

Davidoviç, D. and others (1970). Categorizationof correctionalhomesandclassificationof prisonersin Yugoslavia, Belgrade.

Gashi, R. "Execution of imprisonment sentence in Republic of Albania".

Lazareviq, L. (1970). Kaznei mere bezbednosti u savremenomkrivicnompravu, Belgrade.

Kralev, T. (1997). Resocijalizacijanasoobraqajnitedelikventivozatvorski ambient. Skopje.

Lamers, E. (1961). Die OffenenGefaangnisse in der Nienderberg: Betrachtungen und Erfahrungen, bo Th. Vutenberg: Kriminologije und Vollzug der Freicheitstrafe, Strasburg.

Peters, K. GrundsatzlicheuberErzirung und Straf. Th. Vurtenberger.

Tkaçevski, J. M. , (1971). Savetskoeispravitelnoetrudavoepravo (Sovietcorrectionallabour law), Moscow.

United Nations Congresses on Crime Prevention and Criminal Justice First Congress of UN - 1957. 
